\title{
A COMPREHENSIVE REVIEW OF THE COVID- 19 PANDEMIC AND ITS IMPACT ON GLOBAL ECONOMY
}

\author{
Shalini N \\ Department of CSE \\ Dr. AIT \\ Karnataka, India
}

\author{
Dr.Siddaraju \\ Department of CSE \\ Dr. AIT \\ Karnataka, India
}

\begin{abstract}
The extraordinary erupt of the 2019 novel Covid, named as COVID-19 by the World Health Organization (WHO), put various governments around the globe in a hazardous position. The effect of the COVID-19 scene, prior saw by the occupants of China alone, has now gotten a matter of grave worry for essentially every nation on the planet. The absence of assets for drive forward through the COVID-19 eject got along with the dread of overburdened clinical thought structures has obliged a ton of these nations into a condition of divided or complete lockdown. The measure of lab attested Covid cases has been stretching out at a disturbing rate all through the world, with purportedly in excess of 3 million affirmed cases starting at 30 April 2020. Adding to these loads, diverse trick reports, lie, and unconstrained feelings of dread concerning Covid, are being drifted routinely since the emit of the COVID-19. In light of such acts, we draw on different solid sources to introduce a down and out audit of the enormous number of basic focuses related with the COVID-19 pandemic. Notwithstanding the immediate wellbeing suggestions related with the flare-up of COVID19, this examination features its effect on the worldwide economy. The world is confronting something which it hasn't in the previous few decades and this is what is driving unequivocally to the worldwide monetary emergency. The world has changed and everything is stuck or whenever thought about moving then at an exceptionally moderate movement. Truly, and this has occurred because of the purpose for the worldwide pandemic going on and that is COVID 19.
\end{abstract}

Keywords, COVID-19, Coronavirus, transmission stages, pandemic, worldwide financial effect.

\section{INTRODUCTION}

Coronavirus disease 19 (COVID-19), achieved by a novel Covid, has changed the world basically, in the clinical consideration space, yet furthermore in various pieces of human life.for example, training, transportation, governmental issues, gracefully chain, and so on Contaminated COVID-19 individuals regularly experience respiratory sickness and can recuperate with powerful and fitting therapy techniques. What makes COVID-19 altogether more unsafe and easily spread than various Coronavirus families is that the COVID-19 Covid has gotten astoundingly capable in human-to-human transmissions As the structure of this paper, the COVID-19 contamination has spread rapidly in 214 countries. The United State of America (USA) as of now records with the most imperative COVID-19 cases, more than 3.4 million certified cases and very nearly 215,039 pasings (October 04, 2020)[1].Some different nations like Brazil, India, Russia, and Spain are likewise gigantically impacted. Nonetheless, there are no clinical immunizations to forestall the COVID-19 infection and explicit medications/restorative conventions to battle this transmittable disease[1].

Course of the pandemic in India is diverse regarding mortality and spread of contamination when contrasted with some different nations of the world right now. The social, financial and mental effect of the pandemic is recognizable We believe it's critical to investigate the ways, how individuals have found to adapt to the pandemic circumstance one side with social disconnection on the opposite side that may have never-seen. It is an occasion to discover how individuals are changing their daily practice and propensities while remaining inside their homes.

In setting to Indian government, they are gathering data of spoiled people, travel history of open has been seen and for the accompanying of open adaptable applications are been made. The movement of the data combination for debased is start with crown testing centers in every area around each state. Testing centers are the base of the information that help government to dismember the tainting on the ground level [2]. These resources move data to the administration of prosperity and family government help. Data collection of development history of people is being accumulated by the administration of aeronautics. Enormous data went with the work upset, yet it raises a concern of insurance for people. In this pandemic, countries and their organizations are very ready to assemble and get to their own data which open wouldn't care to share earlier. 


\section{International Journal of Engineering Applied Sciences and Technology, 2020 \\ Vol. 5, Issue 7, ISSN No. 2455-2143, Pages 174-180 \\ Published Online November 2020 in IJEAST (http://www.ijeast.com)}

There are lacunae of acceptable exploration in the current writing with respect to the effect of Covid forced lockdown on every day life, which may should be filled in additional time through the most recent examination.

The snappy climb in the number COVID-19 events in general incited the necessity for ensured countermeasures to control the tragic effects of the COVID-19 outbreak. the present Coronavirus cases the world over is as showed up in fig 1. Nevertheless, before researching the imaginable mechanical responses for COVID-19 pandemic impact the board, we give a comprehensive study of the COVID-19, including its clinical features, examination, treatment, and the impact of its scene on the overall economy [2].

\section{BACKGROUND}

According to the WHO, viral pollutions, particularly the ones achieved by different Covids, continue to emerge and speak to a genuine general clinical issue [1]. Covids are round certain sense RNA contaminations going from 600å - 1400å in distance across, with proteins known as spikes extending from its surface, which award a crown-like structure to them under the electron amplifying focal point. The past twenty years have seen the ascent of a couple of viral scenes with different sorts of Covid in control, for instance, the 2002-2004 SARS$\mathrm{CoV}$ erupt [3], and the later focus east respiratory issue Covid (MERS-CoV) illness of 2012.

The SARS-CoV erupt began in the Guandong district of China and later spread to more than 37 countries around the globe, causing in excess of 8000 pollutions and around 774 passings. The _rst example of MERS-CoV defilement was recognized in Saudi Arabia, which began a gigantic degree erupt in the middle eastern countries that in the end incited 871 fatalities. The COVID-19 erupt got known on 31 December 2019 when 27 occasions of pneumonia of dark etiology were represented at the WHO's country office in China [3]. The point of convergence of the erupt was associated with Wuhan's markdown market for fish and other bright animals, including snakes, bats, and marmots.

Another strain of a significantly irresistible Covid, SARSCoV-2, has been regarded liable for the speedy scene of COVID-19. Perceiving qualities of the contamination consolidate its unfathomably irresistible nature and for the most part long (1-14 days) agonizing period. During this period, an individual can be spoiled by the disease and not show any indications at all. Consequently, people corrupted with the disease may coincidentally fill in as peaceful carriers of the contamination, adding to a high basic regenerative number 2 for the COVID-19 contamination. While a couple of examinations show that SARS-CoV-2 could be frail to warmth and splendid (UV) light, there is no specific treatment or immunizer for the tainting to date, and the organization shows for the contamination are progressing as of this writing[4].

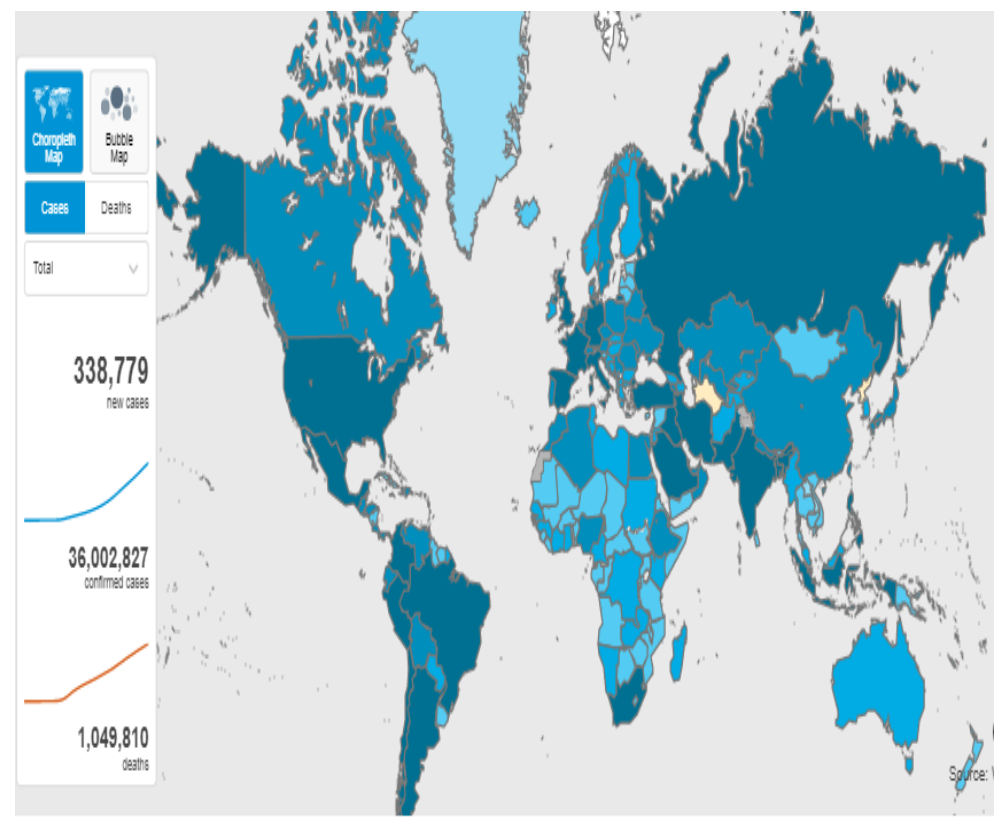

Fig 1. Globally, CEST, 6 October 2020, there have been 35,347,404 confirmed cases of COVID-19, with $1,039,406$ deaths, reported to WHO.

\section{CLINICAL FEATURE}

From the ensuing reports, it is assessed that in $70 \%$ of patients the infection is asymptomatic or with gentle indications, while in the leftover $30 \%$ there is a respiratory disorder with high fever, hack, weakness, and sputum creation .simultaneously, just a small bunch of patients displayed manifestations, for example, sore throat, migraine, myalgia, and windedness ,while side effects, for example, sickness, nasal blockage ,hemoptysis, loose bowels, and conjunctival clog were discovered to be extremely uncommon (allude to Table 1 until serious respiratory disappointment is arrived at who may require ICU affirmation. Hence, information reachable from reports and mandates gave by wellbeing strategy organizations, permit separating the clinical signs of the infection as per the seriousness of the clinical pictures[4].

The COVID-19 may give mellow, moderate, or serious ailment. Among the extreme clinical appearances, there are serious pneumonia, ARDS to intense respiratory misery disorder just as extra aspiratory indications and Systemic intricacies, for example, sepsis, and septic stun. The clinical course of the infection appears to foresee an ideal pattern in most of patients.

In a rate still to be characterized of cases, after about seven days there is an unexpected declining of clinical conditions with quickly exacerbating respiratory disappointment and MOD/MOF numerous organ brokenness disorder .. As a source of perspective, the measures of the seriousness of respiratory inadequacy and the demonstrative models of sepsis and septic stun can be used[7]. 
TABLE 1. List of COVID-19 symptoms.

\begin{tabular}{|l|l|}
\hline \multicolumn{2}{|c|}{ Most Common Symptoms } \\
\hline Fever & $87.9 \%$ \\
\hline Dry Cough & $67.7 \%$ \\
\hline Fatigue & $38.1 \%$ \\
\hline Sputum Production & $33.4 \%$ \\
\hline \multicolumn{2}{|c|}{ Less Common Symptoms } \\
\hline Shortness of Breath & $18.6 \%$ \\
\hline Myalgia / Arthralgia & $14.8 \%$ \\
\hline Sore Throat & $13.9 \%$ \\
\hline Headache & $13.6 \%$ \\
\hline Chills & $11.4 \%$ \\
\hline \multicolumn{2}{|c|}{ Rare Symptoms } \\
\hline Nausea & $5.0 \%$ \\
\hline Nasal Congestion & $4.8 \%$ \\
\hline Diarrhea & $3.7 \%$ \\
\hline Hemoptysis (coughing up blood) & $0.9 \%$ \\
\hline Conjunctival Congestion & $0.8 \%$ \\
\hline
\end{tabular}

Source: WHO

\section{DIFFERENT STAGES OF COVID 19 OUTBREAK}

As per the WHO, the COVID-19 pandemic is respected as having four fundamental classes of transmission that stay obvious all through world to engage better correspondence and comprehension among the nations. a blueprint makes it more straightforward for different nations to execute methods which they think would assist with upsetting the scene, for instance, convincing travel boycotts, closing down schools and universities, and keeping up divided or complete lockdown.

For better agreement, we have depicted the WHO transmission classes as various times of the COVID-19 scene keeping according to a couple media reports. The beginning of various times of the COVID-19 emit in four nations, to be express, China, Spain, Italy, and the USA, have been masterminded in Fig. 4. Entryways help to associate the inward association of sensor centers with the external Internet or World Wide Web. They do this by get-together the data from sensor center points and imparting it to the web system [8].

\section{A. STAGE I - IMPORTED CASES ONLY}

The main time of the COVID-19 eject in a specific country is depicted by its from the start organized scene of the disease, in this case, COVID-19. Stage 1 is when cases are imported from affected nations. Here, the contamination doesn't spread locally - cases uncovered are generally a direct result of the people who have A development history to an affected country. Stage one sees simply these test positive[5].

\section{B. STAGE II - SPORADIC CASES/LOCAL TRANSMISSION}

This is the stage when neighborhood transmission happens and its source is known and can be found. At this stage, people testing positive have interfaced with a patient who has gone outer the country. They are routinely those in close contact with the patient, for example, relatives or other people who have been in contact with the infected. Fewer public are influenced at Stage 2 and it is simpler to perform contact following and contain the spread through self-separating. India is right now in Stage 2[5].

\section{STAGE III - CLUSTERS OF CASES}

The third stage is where the wellspring of the sickness is untraceable; this stage is perceived by people who haven't had travel history getting affected by the contamination - once here spread is inconceivably irresistible and difficult to control. It is the most dreaded stage during which there are a couple of lots of the defilement and it shows up as a scourge. Enormous numbers are tainted making it incredibly difficult to control and contain the spread of the disease[6].

\section{STAGE IV - COMMUNITY TRANSMISSION}

Network transmission is the third phase of an episode. In this stage, as indicated by the report, it turns out to be difficult to follow the chain of transmission of the infection in countless cases. This implies that the infection has begun coursing inside the network and can likewise contaminate those people who have neither ventured out to a nation influenced by the flare-up nor have come into the contact of an individual tainted by the infection. For this situation, a lockdown turns out to be profoundly significant as any individual can spread the infection, paying little heed to their movement history or the individuals they have come in contact with[6]. 


\section{International Journal of Engineering Applied Sciences and Technology, 2020 \\ Vol. 5, Issue 7, ISSN No. 2455-2143, Pages 174-180 \\ Published Online November 2020 in IJEAST (http://www.ijeast.com)}

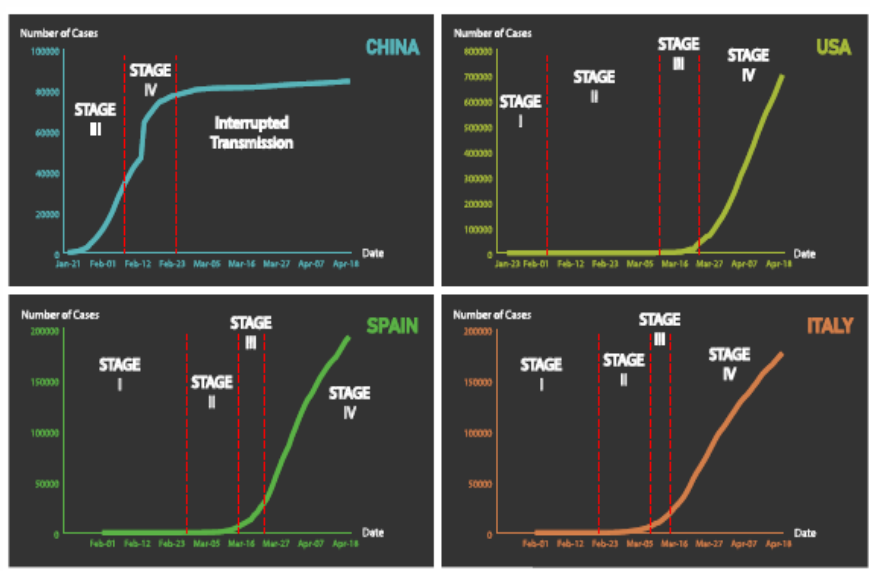

FIGURE 4. Cumulative number of cases of the COVID-19 (data source: WHO situation reports, several media reports).

\section{IMPACT OF THE COVID-19 PANDEMIC ON THE GLOBAL ECONOMY}

\begin{abstract}
While its absolutely hard to tell unquestionably what the financial wickedness from the in general COVID-19 novel Covid pandemic will be, there is wide game-plan among business examiners that it will have phenomenal negative effects on the by and large economy[7]. Early measures predicated that, should the defilement become a general pandemic, most basic economies will lose at any rate 2.4 percent of the worth their outright open yield (GDP) more than 2020, driving business analysts to beginning at now diminish their 2020 figures of by and large cash related improvement down from around 3.0 percent to 2.4 percent. To place this number in setting, generally GDP was assessed at around 86.6 trillion U.S. dollars in 2019 - proposing that basically a 0.4 percent drop in money related improvement adds up to in every practical sense, 3.5 trillion U.S. dollars in lost monetary yield. Notwithstanding, these checks were made going before COVID-19 changing into a general pandemic, and before the execution of sweeping limitations on social contact to stop the spread of the pollution.
\end{abstract}

\section{OIL INDUSTRY}

The effect of COVID-19 and the oil costs war are ending up being a two dimensional emergency for oil, gas, and synthetic substances organizations. Oil costs are dropping because of bombed concurrences on creation cuts and the requirement for synthetics and refined items is easing back from mechanical $\log$ jams and travel limitations in the wake of this worldwide pandemic.
- The presence of Corona illness in December 2019 in China and steady expansionof the plague undeniably cut down interest and cost of the unrefined petroleum. On 31 December 2019 - on the date of detailing of COVID-19 - West Texas Intermediate WTI oil future was exchanging at US \$61.06 and regard dropped to $\$ 23.36$ on 23 March 2020. More than 61 percent fall in the cost of WTI cruel grants something unequivocal of interest irregularity [7].

- Global level travel blacklists close by setting up of overall flights prompts robust diminishing in use of aeronautics turbine fuel (ATF) over the globe. Whole European Union, host to a few acclaimed explorer fights is under certified COVID-19 assault. Undeniably, COVID-19 will lastingly impact in general travel; hence, decrease in utilization of ATF at by and large level will proceed for a more widened period than anticipated [8].

- Lockdown is in power in Italy, Germany, India, UK, South Africa, Morocco, and Spain. Crown driven lockdowns call for individuals to "remain at home" and evade pointless undertakings. Fundamentally, crown limits a wide range of versatility in this manner oil usage by the vehicle zone will without a doubt fall powerfully. Further, abbreviated mechanical and business activities will have diminished usage of fuel[8].

\section{HEALTH CARE AND MEDICAL INDUSTRY}

Medical care fragments across countries are battling to adapt to the enormous awkwardness in gracefully and request, among other SCM challenges. Worldwide clinical flexibly chains are in a powerless state, given assembling plant closures that have prompted a lack of medications, testing units, and other basic things [9].

- Pharmaceutical organizations are attempting to make harmony with this new reality and are searching for arrangements that moderate and ultimately forestall repeats the COVID-19 episode. Governments, medical clinics, speculators, pharma organizations, and related organizations are generally pursuing optimizing clinical preliminaries [10].

- he United States will have an overabundance of 100,000 ventilators, while Western Europe will buy another 30,000 to 50,000 ventilators through the finish of 2020. This lopsided conveyance across districts will rethink non-emergency clinic and home 


\section{International Journal of Engineering Applied Sciences and Technology, 2020 \\ Vol. 5, Issue 7, ISSN No. 2455-2143, Pages 174-180 \\ Published Online November 2020 in IJEAST (http://www.ijeast.com)}

basic consideration models, while installed examination frameworks will restore the develop observing gadgets section post-pandemic[11]. Resmed has dispatched a far off checking answer for ventilators in the U.S. furthermore, Europe through its cloud-based AirView stage for home care[12].

- By the finish of 2020, 33 percent of worldwide clinical preliminaries will be upset, putting $\$ 3$ billion in new item incomes in danger. Disturbed clinical preliminaries and the resulting delay in medication dispatches will prepare for completely virtual preliminaries, and hybridization understanding enrollment, maintenance, and observing will turn out to be all-pervasive[13].

\section{TURISM INDUSTRY}

Because of hindrances compelled in March when the Covid began spreading quickly around the globe, by and large travel went to an unforeseen stop in April and May, accomplishing in general traveler appearances that followed a year earlier's beginning and end out by for all intents and purposes $60 \%$ through the hidden five months of 2020. Subordinate upon when travel limitations will be completely lifted, the World Tourism Organization expects worldwide the development business receipts (for example spending by and large sightseers) to drop between $\$ 910$ billion and $\$ 1.2$ trillion this year, which would hamper the worldwide the development business by 20 years.[14].

- Current circumstances feature diminishes of $58 \%$ to $78 \%$ in overall traveler appearances for the year, dependent upon the speed of the control and the length of development impediments and conclusion of edges, regardless of the way that the perspective remaining parts particularly uncertain (the circumstances are not checks and should not be unraveled in this way).

- The conditions reflect three probably cases of month to month change in appearances from April to December 2020 tolerating that head out limitations begin to be lifted and public edges opened toward the beginning of July (Scenario 1: - 58\%), around the beginning of September (Scenario 2: - 70\%) or toward the beginning of December (Scenario 3: - 78\%). These conditions would put 100 to 120 million direct the development business occupations at risk. [14]

1. This is by a wide edge the most truly awful outcome in the certain game-plan of worldwide the development business since 1950 and would put a surprising consummation to a 10-year period of maintained improvement since the 2009 cash related crisis.[15].

\section{FOOD INDUSTRY}

Relationship with different regions, the effect of the COVID-19 pandemic has not been as veritable on the food business. Certification of food as something central has permitted easily chains related with food things to stay operational. Most likely, according to the Food and Agriculture Organization (FAO) of the United Nations (UN), bundled food request has risen signicantly in the months following the COVID-19 scene. In any case, that doesn't try to communicate that the business has not been affected in any capacity whatsoever. While deftly chains for head food things are kept open, bistros, bistros, and other overabundance food ace networks have been compelled to close down. Moreover, several market proprietors and general stores are reliably _nding themselves unsatisfactory to satisfy the rising necessities inferable from 'alert purchasing' and piling up of food supplies by the masse[16]-[20].

\section{CONCLUSION}

We start this paper with a serious audit of the COVID-19 itself, in which we investigate its clinical highlights, transmission instrument, and end systems. Following this, we talk about the stages the infirmity experiences all through its spread. We in addition list the assorted treatment endeavors being made to stop the pandemic and the preventive measures to be followed till the time that is conceivable. To change the woeful effect of the COVID-19, we also investigate the condition of the general economy following its scene.

\section{ACKNOWLEDGEMENT}

I might want to accept the open door to recognize the help a lot of all who have helped me in the examination.

Without their commitment and guidance, I couldn't ever have had the option to advance with the work in the examination. The data and input gave by companions were incredibly useful.

\section{REFERENCES}

[1].WHO. (Apr. 2020). (WHO Situation Report 101). [Online]. Available:

https://www.who.int/docs/default-

source/coronaviruse/situationreports/\%

20200430-sitrep-101-covid-19.pdf?sfvrsn=2ba4e093_2

[2].World Health Organization. Coronavirus disease (COVID19)

Pandemic. Accessed: Apr. 30, 2020. [Online]. Available: https:// 


\section{International Journal of Engineering Applied Sciences and Technology, 2020 \\ Vol. 5, Issue 7, ISSN No. 2455-2143, Pages 174-180 \\ Published Online November 2020 in IJEAST (http://www.ijeast.com)}

www.who.int/emergencies/diseases/novel-coronavirus-201

[3].M. Cascella, M. Rajnik, A. Cuomo, S. C. Dulebohn, and R. Di Napoli,

[updated 2020 Apr 6], "Features, evaluation and treatment coronavirus (COVID-19)" in StatPearls [Internet]. Treasure Island,

FL, USA: StatPearls Publishing, Jan. 2020. [Online]. Available: https://

www.ncbi.nlm.nih.gov/books/NBK554776/s

[4]. C. Sohrabi, Z. Alsa_, N. O'Neill, M. Khan, A. Kerwan, A. Al-Jabir,C. Iosi_dis, and R. Agha, ' World health organization declares global

emergency: A review of the 2019 novel coronavirus (COVID19)," Int.

J. Surgery, vol. 76, pp. 71_76, Apr. 2020.

[5]. WHO. (Feb. 2020). Report WHO-China Joint Mission Coronavirus Disease 2019 (COVID-19). [Online]. Available: https://www.who.int/docs/default-source/coronaviruse/whochinajoint-

mi\%ssion-on-covid-19-_nal-report.pdf

[6]. World Health Organization. Modes of Transmission of Virus Causing

COVID-19: Implications for IPC Precaution

Recommendations.

Accessed: Apr. 20, 2020. [Online]. Available: https://www. who.int/newsroom/

commentaries/detail/modes-of-transmission\%-of-virus-

causingcovid-

19-implications-for-ipc-precaution-recommendations

[7]. R. Baldwin and E. Tomiura, “'Thinking ahead about the trade impact of COVID-19," Economics in the Time COVID-19, 2020, p. 59

8. V. Surveillances, “The epidemiological characteristics of an outbreak of

2019 novel coronavirus diseases (COVID-19) China, 2020,"

China CDC

Weekly, vol. 2, no. 8, pp. 113_122, 2020.

[8]] A. Cang, J. Blas, and S. Cho. China Oil Demand Has Plunged 20\%

Because of the Virus Lockdown. Bloomberg.com. Feb. 2020.

[Online].

Available: https://www.bloomberg.com/news/articles/202002-02/chinaoil-

demand-is-\%said-to-have-plunged-20-on-virus-lockdown.

[9] S. Meredith. Oil Prices Could Soon Turn Negative as the World Runs

Out of Places to Store Crude, Analysts Warn. CNBC, Apr. 2020.
[Online].

Available: https://www.cnbc.com/2020/04/01/coronavirus-oilpricescould-turn-negat\%ive-as-storage-nears-capacity.html.

[10]M. V. Beusekom, “Doctors: COVID-19 pushing Italian ICUs toward

collapse," Univ. Minnesota (UMN), Mar. 2020. [Online]. Available:

https://www.cidrap.umn.edu/newsperspective/2020/03/doctors-covid19-pu\%shing-italian-icus-toward-collapse.

[11] J. Hockaday. (Mar. 2020). Spain's Healthcare System on Verge of

Collapse as Another 655 Die of Coronavirus. [Online]. Available:

https://metro.co.uk/2020/03/26/spains-healthcare-systemvergecollapse-\%

another-655-die-coronavirus-12459204/

[12] M. Yamaguchi and Y. Kageyama, “Coronavirus: Japan's medical system

on verge of collapse, doctors say," Global News, Apr. 2020.

[Online].

Available:

https://globalnews.ca/news/6836522/coronavirusjapanmedical-system/

[13] W. Feuer, 'WHO of_cials warn health systems are 'collapsing' under

coronavirus: 'This isn't just a bad_u season,"' CNBC, Mar. 2020.

[Online].

Available:

https://www.cnbc.com/2020/03/20/coronaviruswhosays-health-systems-col\%lapsing-this-isnt-just-a-bad_useason.

html

[14]J. Faus, “This is how coronavirus could affect the travel and tourism

industry," World Economic Forum, 3AD. [Online]. Available: https://www.weforum.org/agenda/2020/03/world-travelcoronaviruscovid $19 \%$ -

jobs-pandemic-tourism-aviation/

[15] UNWTO. (Mar. 2020). Impact Assessment of the COVID19 Outbreak on International Tourism. [Online]. Available: https://www.unwto.org/impact-assessment-of-the-covid-19outbreakon-

int\%ernational-tourism13. D. Cheng. Covid 19 Coronavirus_Latest Case Numbers; Are

We Ready to Lift Lockdown? NZ Herald. Apr. 2020. [Online]. Available:

https://www.nzherald.co.nz/nz/news/article.cfm?c_id= 1 \&objectid=12325851. 
[16]Food and Agriculture Organization of the United Nations.

Q\&A: COVID-

19 Pandemic_Impact on Food and Agriculture. Accessed: Apr. 20, 2020.

[Online]. Available: http://www.fao.org/2019-ncov/q-anda/impact-onfood-

and-agriculture/en/

[17] ResearchAndMarkets.com. (Apr. 2020). Global Food \& Beverages

Industry and the Effects of COVID-19_Analysis of Regional

Regulations and Other Government

Policies_ResearchAndMarkets.com.

[Online].

Available:

https://www.businesswire.com/news/home/

20200415005321/en/Global-Food-Be\%verages-Industry-

Effects-

COVID-19

[18] I. Almeida, M. Dorning, and M. G. Perez. Food Makers Get Shot of

Reality Now that Panic Buying Has Waned. Bloomberg.com. Apr. 2020.

[Online]. Available:

https://www.bloomberg.com/news/articles/2020-04-

16/with-panic-buying-wa\%ning-big-food-sees-life-without-

restaurants

[19] V. Bekiempis. Could You Buy a Little Less, Please?': Panic-Buying

Disrupts Food Distribution. The Guardian, Mar. 2020. [Online]. Available:

https://www.theguardian.com/world/2020/mar/23/us-

coronaviruspanic-

buyi\%ng-food

[20] Coronavirus: How do I Get a Food Parcel? BBC News, Apr. 2020.

[Online]. Available: https://www.bbc.com/news/business51737030 